\title{
Effect of Certain Ecological and Agro Techniques on the Incidence of Pink Bollworm, Pectinophora gossypiella (Lepidoptera: Gelechidae) and Spiny Bollworm, Earias Insulana, (Lepidoptera: Noctuidae); on Cotton Plants
}

\author{
Mesbah, H. A., ${ }^{1}$ Kh.A, Abd El Rahman, ${ }^{2}$ A.Z. EL- Naggar ${ }^{2}$, M. A. Massoud ${ }^{1}$ and Haity M. Tadros ${ }^{2}$
}

\begin{abstract}
The present study was conducted on cotton variety Giza 88 during two consecutive seasons of 2009 and 2010 to evaluate and determine the possible use of each of four fertilization types: bio-fertilizer $\left(\right.$ Microbin $\left.^{\circledR}\right)$, Organic, Mineral and bio-+ mineral ones; two foliar nutrients (Greenzit S.P ${ }_{100} \&$ Potasin-F), a bio-pesticide "Radiant" and two plant traps of okra and/or maize in comparison to a standard insecticide - Chlorpyrifos, in an Integrated Pest Management (IPM) program for controlling the pink bollworm, Pectinophora gossypiella (Saunders) \& spiny bollworm, Earias insulana (Boisd.).

The obtained results indicated that the bio-fertilized cotton plants were somewhat less infested with pink \& spiny bollworm, in comparison to the organic, mineral and organic-bio fertilized ones. Spraying of both the foliar nutrients - Potasin- F + Greenzit $\mathbf{S P}_{100}$, the biopesticidRadiant $^{\circledR}$ and/or the conventional pesticide Chlorpyrifos on the surrounded cotton plants by okra and / or maize plants gave lower means values of pink \& spiny bollworm infestation. Also, the encircled cotton plants by okra and / or maize plants without any spraying treatments gave lower significant means of infestation in both the successive seasons of study.
\end{abstract}

\section{INTRODUCTION}

The cotton bollworms are regarded as one of the most destructive insect-pests of cotton plants in Egypt. Cotton is considered the preferred host plant for bollworms. The indiscriminate use of insecticides has caused numbers of ecological, economical and social problems worldwide including Egypt, besides the proved resistance of several insect pests to insecticides. Foliar fertilization using different formulated nutritive elements might be a good tool to produce a tolerant and profitable cotton plants that compete with weeds and able to outgrow and overcome diseases and insect damage (Mesbah et.al. 2000, 2004 and 2005). Foliar nutrients can also correct the resulting deficiencies due to the lack of certain nutrients, which are required in large amounts (macro-elements) and / or required in trace amounts (micro - elements) (Locke and Eck, 1965 ,Michaeal, 1970 and EI-Naggar,1998, 2003).

\footnotetext{
${ }^{1}$ Department of plant protection, Faculty of Agriculture (Saba-Bacha) Alexandria University

${ }^{2}$ Plant Protection Res., Institute Agric. Res. Centre., Alex., Egypt

Email:alyelnaggar31@gmail.com, alyelnaggar@ymail.com

Received December 29, 2013, Accepted March11, 2014
}

In addition, as one of initiated and followed ecotechnological principles that concern the habitat diversification in agro-ecosystem, intercrops or interplants have also been used successfully as trap crop systems to divert pest infestations away from cotton. This has allowed cotton pests to be managed culturally rather than by the use of synthetic insecticides, thereby reducing the amount of insecticides used against these pests in cotton. The use of trap plants in cottoncropping systems exemplifies the (push-pull) strategy (Pyke et al., 1987), where, the pest is pulled in by the trap crops, often with the assistance of tactics designed to push it off the main crop.

Therefore, objectives of the present study are adopted to evaluate the integral effect of some agro technical traits, as pest control measures against the pink \& spiny bollworms. For that goal : 1) the fertilization types; bio-fertilizer $\left(\right.$ Microbin $\left.^{\circledR}\right)$, Organic, Mineral and bio-+ mineral fertilization 2) the foliar fertilizers (Greenzit $\mathrm{Sp}_{100}$ \& Potasin-F), 3) the synthetic (OP) insecticide (Chlorpyrifos), 4) the bio- pesticide (Radiant ${ }^{\mathbb{B}}$ ) and 5) two plant traps of maize and / or okra plants, were involved in field applications on growing cotton plants, variety - Giza 88 in 2009 and 2010 cotton seasons for determining their possible use in a program of Integrated Pest Management (IPM) of pink \& spiny bollworm.

\section{MATERIALS AND METHODS}

Field experiments were carried out at the experimental farm of Fac. Agric. Saba-Bacha, Alex. Univ. Alexandria, Egypt, throughout two successive cotton growing seasons of 2009 and 2010. In both seasons an area of half feddan was cultivated with cotton variety "Giza $88^{\text {" }}$ on May the $28^{\text {th }}$ and April the $24^{\text {th }}$, respectively. The experimental design was the split one with three replicates as well as untreated check.

The experimental areas were divided into plots $(0.01$ feddan). Each plot was separated from the adjacent one by a half - meter belt to minimize the interference of spray drift from one treatment to the other. In season of 2009 , the initiated field experiment was divided in three subsets. In the $1^{\text {st }}$ subset, cotton seeds were treated with 
"Microbin ${ }^{\circledR} "$ as bio-fertilizer in addition to the half of recommended rates of mineral fertilizers; the $2^{\text {nd }}$ one was cultivated and considered as organic cotton; fertilized by applying composted goat manure at a rate of $20 \mathrm{~m}^{3}$ per feddan. While the $3^{\text {rd }}$ subset was cultivated and treated as conventional cotton; fertilized by the recommended rates of mineral fertilizers.

The experimental area of each subset included 11 treatments in addition to the untreated check. Each treatment was replicated 3 times. The following treatments were: 1) Foliar fertilizers: "Greenzit $\mathrm{SP}_{100}$ \& Potasin -F"; 2) Synthetic insecticide "Chlorpyrifos"; 3) A bio-pesticide "Radiant". Spraying treatments were applied at three phenological stages, i.e., beginning of flowering period, fifty percentage of flowering and the beginning of fruiting period;4) Plant traps (okra \& maize).

The adjusted plant traps of corn maize and okra in each subset was performed in the following pattern: 1) plots of treated cotton plants surrounded by untreated pelts of maize and / or okra plants. 2) Plots of untreated cotton plants surrounded by untreated pelts of maize and /or okra plants. 3) Cotton plants of the untreated control without plant traps. In cotton season of 2010 the followed experimental designation was as same as season 2009; in addition to a fourth subset treated with organic fertilizer, plus the dressing of cotton seeds with the bio-fertilizer, "Microbin ${ }^{\mathbb{B}}$ ". Sprayings were performed using knapsack sprayer (20 L).

\section{- Estimation of pink \& spiny bollworms infestation:}

Weekly inspections were done to determine the infestation levels of pink \&spiny bollworms over ten weeks during both seasons. Samples of 10 green bolls / plot were taken randomly; 30 green bolls were examined for each treatment. In each sample, bolls were inspected externally before dissection and then internally. Infestation levels were based on the existence of injury symptoms regardless of the presence of the larvae. Statistical analysis using "F" and "L.S.D" tests for the comparison and evaluation of the tested treatments were used.

\section{- Tested compounds}

\section{-Foliar fertilizers}

-Greenzit $\mathbf{S P}_{\mathbf{1 0 0}}$ is produced by Ciba Geigy limited, (Basal, Swiss) and the main components are: EDTA $\mathrm{Na}_{2} \mathrm{Mn}(40 \%)$ and EDTA $\mathrm{Na}_{2} \mathrm{Zn}(43 \%)$ supplemented by $\mathrm{Ca}(0.054), \mathrm{Fe}(5.40)$, Mo $(0.027) \mathrm{Mg}(0.54) \mathrm{Ni}$ (0.005) Mn (5.54) Cu (0.005) Zn (70.27) gm / Kg.

-Potasin F: The main components are: N.P.K. (0:10:30), 30\% potassium oxide, $10 \%$ fifth potassium oxide.

\section{-The Agrochemical pesticides}

Spinetoram (Radiant 12 SC):

The semi synthetic compound is the second generation of spinosyns group. It is a trademark of Dow Agro Sciences Co (Dow, England).

\section{- Organophosphorous compound:}

Chlorpyrifos or Dursban ${ }^{\circledR} 48 \%$ (EC); 0,0 diethyl 03,5,6 trichloro-2-pyridyl phosphorothioate (Dow, England).

\section{RESULTS AND DISCUSSIONS}

-Effect of fertilization types, foliar nutrients, pesticidal application and plant traps on the incidence of the spiny bollworms infestation

\section{-Season of 2009}

The illustrated results in Table (1) are expressed as means numbers of detected spiny bollworm larvae per ten bolls. All of the bio-fertilized cotton plants indicated low levels of spiny bollworms infestation in all of the done spraying treatments of foliar nutrients or / and pesticides on the trapped cotton plants by okra plants $(0.90-1.06$ larvae / 10 bolls $)$ and / or maize plants (1.03 - 1.2 larvae / 10 bolls) compared with untreated check 1.93 larvae $/ 10$ bolls. Also, the trapped cotton plants by okra and / or maize plants without any spraying treatments gave a semi equal insignificant means of infestation amounted to 1.13, 1.23 larvae / 10 bolls, in respect. These means values were insignificantly different and merely equal to the deduced means values of larval infestation for the biofertilized and foliar sprayed untrapped cotton plants, with either the tested nutrients or pesticides and comprised 1.13 - 1.30 larvae / 10 bolls. Comparatively, for the other organically or / and minerally fertilized ones, more or less higher means of infestation with spiny bollworm larvae were obtained but still less than the untreated check $(1.90,1.90$ larvae $/ 10$ bolls, respectively) and ranged from 0.93 to $1.1 \& 1.06$ to 1.26 larvae / 10 bolls and from 1.1 to $1.2 \& 1.06$ to 1.16 larvae / 10 bolls for the organic and minerally fertilized plants, respectively in the trapped cotton plants by okra and maize plants, in respect.

The consequent foliar treatment of Potasin-F + Greenzit $\mathrm{SP}_{100}$ on the encircled cotton plants with okra plant traps gave the lowest level of spiny bollworms infestation of the bio-fertilized plants (1.06 larvae / 10 bolls), followed by the treatments of Radiant ${ }^{\circledR}$ and / or Chlorpyrifos (0.96, 0.90 larvae / 10 bolls, respectively). These means values of spiny bollworms infestation were insignificantly different in the performed foliar treatments on the trapped cotton plants by maize plants and ranged from 1.03 for Chlorpyrifos to 1.2 larvae / 10 bolls for the treatment of Radiant ${ }^{\circledR}$, in comparison to the untreated check (1.93 larvae /10 bolls) (Table, 1). 
Remarkedly, the insignificant efficiency of each evaluated fertilization type, integrating with the other tested agro-eco techniques was proved by the deduced insignificant means values of spiny bollworm

Table 1. Effect of foliar treatments, plant traps and fertilization types on the mean numbers of Earias insulana larvae per ten bolls throughout the growing season of 2009

\begin{tabular}{|c|c|c|c|}
\hline \multirow{3}{*}{ Treatments } & \multicolumn{3}{|c|}{ Mean Numbers of larvae per ten bolls } \\
\hline & \multicolumn{3}{|c|}{ Fertilization types } \\
\hline & Bio-Fertilization & Organic Fertilization & Mineral Fertilization \\
\hline \multicolumn{4}{|c|}{ A- Plant Trap of Okra } \\
\hline $\begin{array}{c}\text { Potasin }-\mathrm{F}+\text { Greenzit } \mathrm{SP}_{100} \\
5 \mathrm{~m} / \mathrm{L}+0.3 \mathrm{gm} / \mathrm{L}\end{array}$ & $1.06 \mathrm{bc}$ & $1.06 \mathrm{~b}$ & $1.26 \mathrm{~b}$ \\
\hline $\begin{array}{r}\text { Radient } \\
0.4 \mathrm{ml} / \mathrm{L} \\
\end{array}$ & $0.96 \mathrm{bc}$ & $1.1 \mathrm{~b}$ & $1.06 \mathrm{~b}$ \\
\hline $\begin{array}{c}\text { Dursban } \\
5 \mathrm{~m} / \mathrm{L}\end{array}$ & $0.90 \mathrm{c}$ & $0.93 \mathrm{~b}$ & $1.06 \mathrm{~b}$ \\
\hline Plant Trap & $1.13 \mathrm{bc}$ & $1.26 \mathrm{~b}$ & $1.23 \mathrm{~b}$ \\
\hline \multicolumn{4}{|c|}{ B- Plant Trap of Maize } \\
\hline $\begin{array}{c}\text { Potasin }-\mathrm{F}+\text { Greenzit } \mathrm{SP}_{100} \\
5 \mathrm{~m} / \mathrm{L}+0.3 \mathrm{gm} / \mathrm{L} \\
\end{array}$ & $1.1 \mathrm{bc}$ & $1.2 \mathrm{~b}$ & $1.16 \mathrm{~b}$ \\
\hline $\begin{array}{r}\text { Radient } \\
0.4 \mathrm{ml} / \mathrm{L} \\
\end{array}$ & $1.2 \mathrm{bc}$ & $1.1 \mathrm{~b}$ & $1.13 \mathrm{~b}$ \\
\hline $\begin{array}{c}\text { Dursban } \\
5 \mathrm{~m} / \mathrm{L} \\
\end{array}$ & $1.03 \mathrm{bc}$ & $1.1 \mathrm{~b}$ & $1.06 \mathrm{~b}$ \\
\hline Plant Trap & $1.23 \mathrm{bc}$ & $1.26 \mathrm{~b}$ & $1.4 \mathrm{~b}$ \\
\hline \multicolumn{4}{|c|}{ C- Cotton Plants without plant traps } \\
\hline $\begin{array}{c}\text { Potasin }-\mathrm{F}+\text { Greenzit } \mathrm{SP}_{100} \\
5 \mathrm{~m} / \mathrm{L}+0.3 \mathrm{gm} / \mathrm{L} \\
\end{array}$ & $1.13 \mathrm{bc}$ & $1.16 \mathrm{~b}$ & $1.23 \mathrm{~b}$ \\
\hline $\begin{array}{r}\text { Radient } \\
0.4 \mathrm{ml} / \mathrm{L} \\
\end{array}$ & $1.30 \mathrm{~b}$ & $1.13 \mathrm{~b}$ & $1.36 \mathrm{~b}$ \\
\hline $\begin{array}{c}\text { Dursban (Chlorpyrifos) } \\
5 \mathrm{~m} / \mathrm{L} \\
\end{array}$ & $1.26 \mathrm{bc}$ & $1.3 \mathrm{~b}$ & $1.13 \mathrm{~b}$ \\
\hline Untreated Check & $1.93 \mathrm{a}$ & $1.90 \mathrm{a}$ & $1.90 \mathrm{a}$ \\
\hline F Calculated & 3.768 & 3.214 & 2.801 \\
\hline F Tabulated & 1.87 & 1.87 & 1.87 \\
\hline $\operatorname{LSD}_{.05}$ & 0.377 & 0.372 & 0.387 \\
\hline Significant & $* * *$ & $* * *$ & $* * *$ \\
\hline
\end{tabular}

Table 2. Effect of Fertilization types on the mean numbers of Spiny bollworm larvae per ten bolls throughout the growing season of 2009

\begin{tabular}{lc}
\hline \multicolumn{1}{c}{ Type of Fertilizers } & Mean Numbers of larvae per ten bolls \\
\hline Bio-Fertilization & 1.18 \\
\hline Organic Fertilization & 1.20 \\
\hline Mineral Fertilization & 1.25 \\
\hline F Calculated & 0.208 \\
F Tabulated & 6.94 \\
\hline Significant & $\mathrm{N} . \mathrm{S}$ \\
\hline N.S $:$ Not Significant
\end{tabular}

infestation in Table, 2, amounted to $1.18,1.2$ and 1.25 larvae / 10 bolls for the bio-fertilized, organic and mineral fertilized plants, in respect. 


\section{-Season of 2010}

As to the elucidated results of season 2009, the demonstrated results in Table (3) declare the resulted integral effects of each of the adopted fertilization type, foliar sprayings and sown plant traps of okra and / or maize plants around the plantation yard of growing cotton plants, on the measured levels of spiny bollworm infestation.

Herein, spraying treatments of the foliars; Potasin-F + Greenzit $\mathrm{Sp}_{100}$ and the synthetic insecticide; Chlorpyrifos on the bio-fertilized and encircled cotton plants by the traps of okra plants revealed the lowest means numbers of inspected larvae of spiny bollworms (0.92\&1.0 larvae /10 bolls, in respect), followed by Radiant $^{\circledR}$ (1.03 larvae $/ 10$ bolls); while, for the surrounded ones by the traps of maize plants the results indicated the absence of significant differences between most of the comparatively lower calculated means numbers of inspected larvae / 10 bolls which ranged from 0.92 for the treatment of Chlorpyrifos to 1.14 larvae /10 bolls for the treatment of Radiant ${ }^{\circledR}$ compared with the untreated check- (2.03 larvae /10 bolls) (Table, $3)$.

Also, the unsprayed cotton plants; and encircled only by okra and / or maize plants gave an insignificant mean number of lowered infestation amounted to $1.18 \&$ 1.29 larvae / 10 bolls, in respect.

Comparatively, for the organic, the mineral or / and the organo-biofertilized cotton plants, and surrounded with each of the sown okra and / or maize plant traps; the revealed integral effects on the sprayed or / and the unsprayed cotton plants in each case of treatmental integration, were expressed in low insignificant means of spiny bollworm infestation ranged between $0.96 \&$ 1.07 and $1.0 \& 1.18 ; 0.81 \& 1.07$ and $1.0 \& 1.11 ; 0.96$ $\& 1.14$ and $1.14 \& 1.29$ larvae / 10 bolls in the mineral, organic and organo-biofertilized cotton plants, in respect (Table, 3). Compared to the untreated check $(2.14,2.07 \& 2.0$ larvae of spiny bollworm /10 bolls, respectively (Table, 3 ).

The valuable effect of integrally applied foliar nutrients (Potasin-F + Greenzit $\mathrm{Sp}_{100}$ ) on the mineral, organic and organo-biofertilized, on the cotton plants without okra and / or maize plants was also recorded and showed low insignificant mean values, of 1.14, 1.14, 1.14 larvae / 10 bolls, in respect, versus, 1.33$1.11,1.03-1.25,1.37-1.29$, respectively larvae / 10 bolls in case of applying Radiant $\left.{ }^{(}\right)$and / or Chlorpyrifos sprays, regardly, on these unsurrounded cotton plants by okra / maiz of the tested plant traps (Table, 3).

Noticeably, the insignificant efficiency of each experimented fertilization type, integrating with the other tested agro - ecotechniques was assured by the calculated insignificant low means values of spiny bollworm infestation $(1.18,1.17,1.12$ and 1.23 for the bio, mineral organic and organo-biofertilized plants, in respect,(Table, 4). Herein, our formerly explained results; convidenced by the statistical analysis of data, confirm the efficient role of followed "push-pull" strategy in the habitat manipulated agro-ecosystem of cotton field, in accord integration with the assessed effects of fertilization types; applied foliar sprays of tested nutrients and pesticides on the surrounded cotton plants by the interplanted traps of okra and / or maize plants.

Moreover, the above cited results are ascertained by the concluded results by Thimmaiah and Raju (1991) who observed that the highest average of eggs laid by the cotton bollworms (Earias vittella and Heliothis armigera) on the used okra plants as a trap crop in cotton fields during two seasons. Wu et al. (1991) showed that interplanting maize at $120-150$ plants per $\mathrm{mu}(1 \mathrm{mu}=0.067 \mathrm{ha})$ in cotton fields increased the populations of Araneae, Coccinllidae and Chrysopidae by $62.8-115.7 \%$ compared with control fields. Maize also acted as a trap crop for Heliothis [Helicoverpa], reducing the $2^{\text {nd }}$ generation of eggs and the damage of cotton.

Moreover, Khan and Pickett (2004) declared that the use of trap crops in cotton - cropping systems exemplifies the " push-pull " strategy, where, the pest is pulled in by the trap crops, often with the assistance of tactics designed to push it off the main crop. The same concept of this strategy was explained by Njihia et al. (2005) who showed that maize is the most important food crop among the control strategies, the habitat management" push-pull " was identified and demonstrated by 25 selected contact farmers in their farms.

The highest reduction in the cotton bollworm infestation was induced by the use of Chlorpyrifos, Tracer $^{\circledR}$ (Spinosad) and Methoxyfenozide ${ }^{\circledR}$, (AbdelRhman, 2004). The obtained results by Purothit and Deshpand (1994) were in full agreement with the present aforementioned and illustrated findings. ELNaggar (2003) and Mesbah et al. (2004) illustrated that the application of Baythroid $^{\mathbb{R}}$ with Greenzit S.P 100 effectively lowered spiny bollworms infestation.

Abd EL-Rahman et al. (2009) stated that the use Vantex (gamma -cyhalothrin) at $100 \mathrm{ml}$ followed by Spinetoram at $70 \mathrm{ml}$ mixed with g. -cyhalothrin at $30 \mathrm{ml}$ gave the highest reduction of spiny bollworm Earias insulana in the $1^{\text {st }}$ season. Moreover, spinetoram at 100 $\mathrm{ml} /$ fed. gave the highest reduction of spiny bollworm in 2006 and 2007 seasons. Also, EL-Naggar (2009) \& 
EL-Naggar and Tawfeek (2012) stated that the foliar treatment with Easterna Aminofert / Greenzit S.P.P / Spinosad and Easterna. / Greenzit S.P 100 with Spinosad

Table 3. Effect of foliar treatments, plant traps and fertilization types on the mean numbers of Earias insulana larvae per ten bolls throughout the growing season of 2010

\begin{tabular}{|c|c|c|c|c|}
\hline \multirow[t]{3}{*}{ Treatments } & \multicolumn{4}{|c|}{ Mean Numbers of larvae per ten bolls } \\
\hline & \multicolumn{4}{|c|}{$\begin{array}{l}\text { Fertilization types } \\
\end{array}$} \\
\hline & Bio Fertil. & Mineral Fertil. & Organic Fertil. & Bio+Organic Fertil. \\
\hline \multicolumn{5}{|c|}{ A- Plant Trap of Okra } \\
\hline $\begin{array}{c}\text { Potasin }-\mathrm{F}+\text { Greenzit } \mathrm{SP}_{100} \\
5 \mathrm{~m} / \mathrm{L}+0.3 \mathrm{gm} / \mathrm{L} \\
\end{array}$ & $0.92 \mathrm{c}$ & $1 \mathrm{~b}$ & $0.96 \mathrm{bc}$ & $1.07 \mathrm{bc}$ \\
\hline $\begin{array}{r}\text { Radient } \\
0.4 \mathrm{ml} / \mathrm{L} \\
\end{array}$ & $1.03 \mathrm{bc}$ & $1.07 \mathrm{~b}$ & $0.88 \mathrm{bc}$ & $0.96 \mathrm{c}$ \\
\hline $\begin{array}{c}\text { Dursban } \\
5 \mathrm{~m} / \mathrm{L}\end{array}$ & $1 \mathrm{c}$ & $0.96 \mathrm{~b}$ & $0.81 \mathrm{c}$ & $1.03 \mathrm{bc}$ \\
\hline Plant Trap & $1.18 \mathrm{bc}$ & $1.03 \mathrm{~b}$ & $1.07 \mathrm{bc}$ & $1.14 \mathrm{bc}$ \\
\hline \multicolumn{5}{|c|}{ B- Plant Trap of Maize } \\
\hline $\begin{array}{c}\text { Potasin }-\mathrm{F}+\text { Greenzit } \mathrm{SP}_{100} \\
5 \mathrm{~m} / \mathrm{L}+0.3 \mathrm{gm} / \mathrm{L} \\
\end{array}$ & $1.07 \mathrm{bc}$ & $1 \mathrm{~b}$ & $1.11 \mathrm{bc}$ & $1.14 \mathrm{bc}$ \\
\hline $\begin{array}{r}\text { Radient } \\
0.4 \mathrm{ml} / \mathrm{L} \\
\end{array}$ & $1.14 \mathrm{bc}$ & $1.14 \mathrm{~b}$ & $1 \mathrm{bc}$ & $1.14 \mathrm{bc}$ \\
\hline $\begin{array}{c}\text { Dursban } \\
5 \mathrm{~m} / \mathrm{L}\end{array}$ & $0.92 \mathrm{c}$ & $1.03 \mathrm{~b}$ & $1.03 \mathrm{bc}$ & $1.18 \mathrm{bc}$ \\
\hline Plant Trap & $1.29 \mathrm{bc}$ & $1.18 \mathrm{~b}$ & $1.11 \mathrm{bc}$ & $1.29 \mathrm{bc}$ \\
\hline \multicolumn{5}{|c|}{ C- Cotton Plants without plant traps } \\
\hline $\begin{array}{c}\text { Potasin }-\mathrm{F}+\text { Greenzit } \mathrm{SP}_{100} \\
5 \mathrm{~m} / \mathrm{L}+0.3 \mathrm{gm} / \mathrm{L}\end{array}$ & $1.48 \mathrm{~b}$ & $1.14 \mathrm{~b}$ & $1.14 \mathrm{bc}$ & $1.14 \mathrm{bc}$ \\
\hline $\begin{array}{r}\text { Radient } \\
0.4 \mathrm{ml} / \mathrm{L} \\
\end{array}$ & $1.48 \mathrm{~b}$ & $1.33 \mathrm{~b}$ & $1.03 \mathrm{bc}$ & $1.37 \mathrm{~b}$ \\
\hline $\begin{array}{c}\text { Dursban } \\
5 \mathrm{~m} / \mathrm{L}\end{array}$ & $1.18 \mathrm{bc}$ & $1.11 \mathrm{~b}$ & $1.25 \mathrm{~b}$ & $1.29 \mathrm{bc}$ \\
\hline Untreated Check & $2.03 \mathrm{a}$ & $2.14 \mathrm{a}$ & $2.07 \mathrm{a}$ & $2 \mathrm{a}$ \\
\hline F Calculated & 3.224 & 4.878 & 4.145 & 3.585 \\
\hline F Tabulated & 1.87 & 1.87 & 1.87 & 1.87 \\
\hline $\mathrm{LSD}_{.05}$ & 0.454 & 0.404 & 0.44 & 0.392 \\
\hline Significant & $* * *$ & $* * *$ & $* * *$ & $* * *$ \\
\hline
\end{tabular}

Table 4. Effect of Fertilization types on infestation with Earias insulana during season of 2010

\begin{tabular}{lc}
\hline \multicolumn{1}{c}{ Type of Fertilizers } & Mean Numbers of larvae per ten bolls \\
\hline Bio-Fertilization & 1.18 \\
\hline Mineral Fertilization & 1.17 \\
\hline Organic Fertilization & 1.12 \\
\hline Organic + Bio-Fertilization & 1.23 \\
\hline F Calculated & 0.427 \\
F Tabulated & 2.75 \\
\hline LSD..05 & - \\
\hline Significant & N.S \\
\hline N.S : Not Significant & $*$ Significant
\end{tabular}

or / and Chlorpyrifos decreased the incidence of spiny bollworm infestation in cotton season of $2006 \& 2007$. 
-Effect of fertilization types, foliar nutrients, pesticidal application and plant traps on the incidence of the pink bollworms infestation

\section{- Season of 2009}

The illustrated results in Table (5) are expressed as means numbers of detected pink bollworm larvae per ten of inspected bolls. Herein, all of the bio-fertilized cotton plants indicated low levels of pink bollworm infestation in all of the done spraying treatments of foliar nutrients or / and pesticides on the trapped cotton plants by okra plants $(0.83-0.96$ larvae / 10 bolls $)$ and / or maize plants $(0.9-1.13$ larvae / 10 bolls $)$ compared with the untreated check (1.9 larvae /10 bolls). Also, the trapped cotton plants by okra and / or maize plants without any spraying treatments gave a semi equal insignificant means of infestation amounted to $1.03 \& 1.23$ larvae / 10 bolls, in respect. These means values were insignificantly different and merely equal to the deduced means values of larval infestation for the bio-fertilized and foliar sprayed untrapped cotton plants, with either the tested nutrients or pesticides and comprised $1.06-1.13$ larvae / 10 bolls. Comparatively, for the other organically or / and minerally fertilized, more or less higher means of infestation with pink bollworm larvae were obtained but still less than the untreated check (1.86, 1.76 respectively) and ranged from 1.0 to $1.26 \&$ from 0.93 to 1.1 larvae / 10 bolls for the organic\& minerally fertilized and trapped cotton plants by okra plants, while, for the trapped ones by maize plants these means values ranged from 1.06 to 1.16 \& from 1.13 to 1.2 larvae / 10 bolls, in respect (Table, 5).

The consequent foliar treatment of Potasin-F + Greenzit $\mathrm{SP}_{100}$ on the encircled cotton plants with okra plant gave the lowest level of pink bollworms infestation of the bio-fertilized plants (0.86larvae / 10 bolls), followed by the treatments of Radiant ${ }^{\circledR}$ and / or Dursban $^{\circledR}$ (0.96\& 0.83 , respectively). These means values of pink bollworms infestation were insignificantly different between the applied foliar treatments on the trapped cotton plants by maize plants and ranged from 0.90 for Dursban ${ }^{\circledR}$ to 1.13 larvae / 10 bolls for Potasin-F + Greenzit $\mathrm{SP}_{100}$, in comparison to the untreated check (1.9 larvae /10 bolls) (Table, 5).

Remarkedly, the efficiency of each evaluated fertilization type (integrating with the other tested agroeco techniques) was proved by the deduced insignificant means values of pink bollworm infestation of 1.1 larvae / 10 bolls for the bio-fertilized, 1.20 for the organic and 1.21 larvae / 10 bolls for the mineral fertilized plants (Table,6).

\section{-Season 2010}

As to the elucidated results of season 2009, the demonstrated results in Table (7) declare the resulted integral effects of each of the conducted fertilization type, foliar sprayings and sown plant traps of okra and / or maize plants around the plantation yard of growing cotton plants on the measured levels of pink bollworm infestation; expressed as mean number of larvae / 10 bolls.

In the initiated spraying treatments of the foliars; Potasin-F + Greenzit $\mathrm{Sp}_{100}$ and the synthetic insecticide; Dursban $^{\circledR}$ on the bio-fertilized cotton plants and encircled by the sown plant traps of okra gave the lowest means numbers of pink bollworms $(0.62 \& 0.62$ larvae /10 bolls, in respect), followed by Radiant ${ }^{\circledR}(0.77$ larvae $/ 10$ bolls). While, for the surrounded cotton plants by the sown plant traps of maize the results indicated the absence of significant differences between most of the comparatively lower calculated means numbers of inspected larvae / 10 bolls which ranged from 0.70 for the treatment of Dursban ${ }^{\circledR}$ to 0.85 larvae $/ 10$ bolls for the treatment of Radiant ${ }^{\circledR}$ compared with untreated check (1.62 larvae /10 bolls, (Table, 7).

Also, the unsprayed cotton plants; and encircled only by okra and / or maize plants gave insignificant means numbers of lowered infestation amounted to 0.88 \& 1.07 larvae / 10 bolls, in respect. These above shown means values were also insignificantly different and merely equal to the calculated means values of estimated lower larval infestation of the mono-cultured bio-fertilized and foliary sprayed cotton plants, with either the tested nutrients or pesticides and comprised $0.81-0.88$ larvae / 10 bolls (Table, 7).

Comparatively, the valuable use of foliar nutrients sprays of Potasin-F + Greenzit $\mathrm{Sp}_{100}$ on the minerally, the organically or / and the organo-biofertilized cotton plants, and surrounded with each of the sown okra and / or maize plant traps was proved. Whereas, the revealed integral effects for the sprayed or / and unsprayed plants in each case of treatmental integration, indicated low insignificant means of pink bollworms infestation amounted to $0.66-0.77 \& 0.70-0.85$ for the mineral plants; $0.66-1.11 \& 0.74-0.81$ for the organic and $0.92-1.22 \& 1.07-1.29$ larvae / 10 bolls for the organo-biofertilized plants in respect, (Table, 7). Compared to the untreated check $(1.40,1.81 \& 1.74$ larvae of pink bollworm /10 bolls, respectively (Table, 7).

The valuable effect of integrally applied foliar nutrients (Potasin-F + Greenzit $\mathrm{Sp}_{100}$ ) on the mineral, organic and organo-biofertilized, but not encircled cotton plants with okra and / or maize plants was also recorded and showed low insignificant means values, of 
$1.03,0.96 \& 1.14$ larvae / 10 bolls, in respect, versus, $0.81-0.92,0.81-0.85$ and $1.00-1.03$, respectively larvae / 10 bolls in case of applying Radiant ${ }^{(\mathbb{R}}$ and / or
Chlorpyrifos sprays, regardly, on these encircled cotton plants by each of the tested plant traps (Table, 7).

Table 5. Effect of foliar treatments, plant traps and fertilization types on the mean numbers of pink bollworm in the growing season of 2009

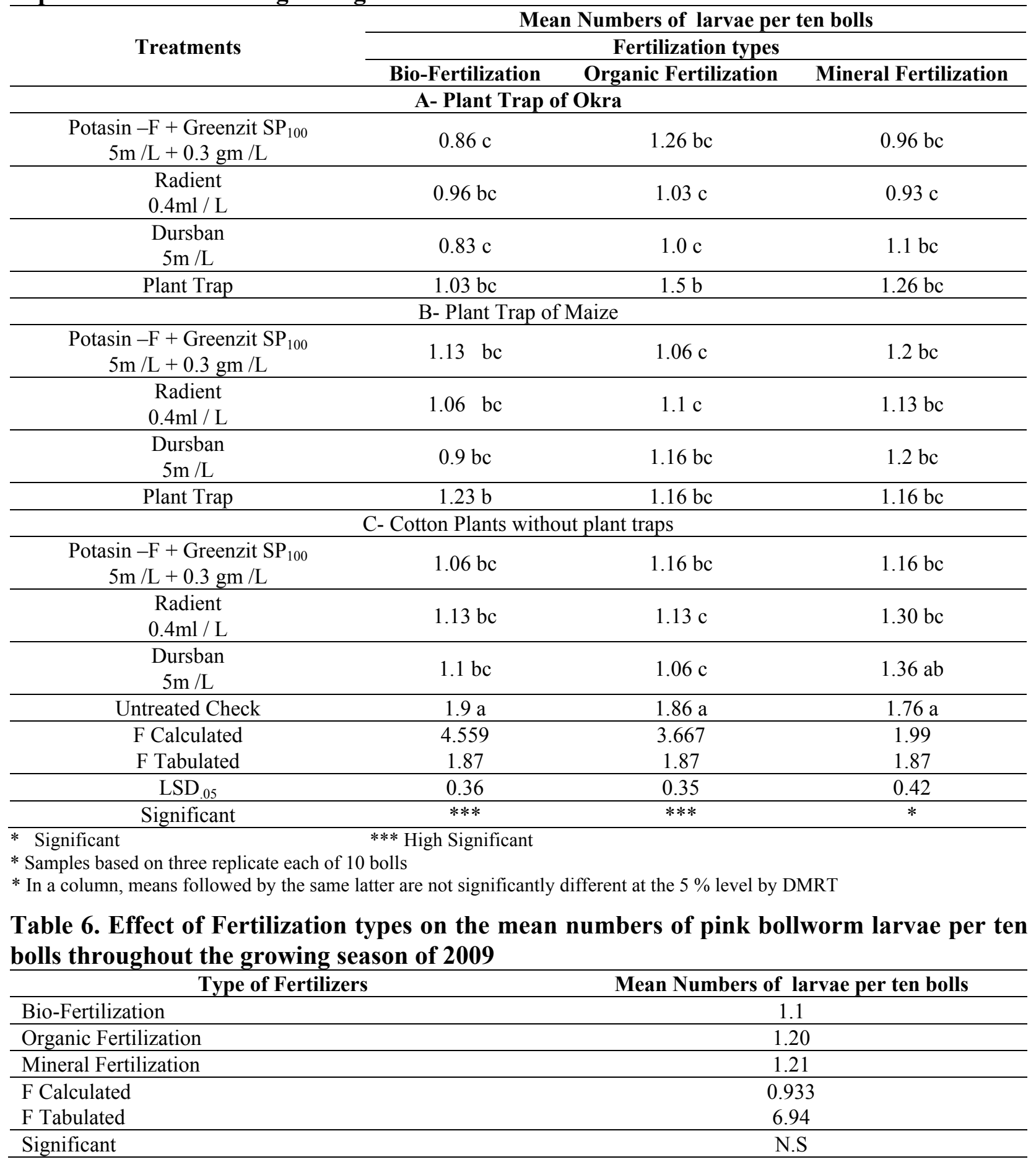

N.S :Not Significant 
Table 7. Effect of foliar treatments, plant traps and fertilization types on the mean numbers of Pectinophora gossypiella larvae per ten bolls throughout the growing season of 2010

\begin{tabular}{|c|c|c|c|c|}
\hline \multirow[t]{3}{*}{ Treatments } & \multicolumn{4}{|c|}{ Mean Numbers of larvae per ten bolls } \\
\hline & \multicolumn{4}{|c|}{$\begin{array}{l}\text { Fertilization types } \\
\end{array}$} \\
\hline & Bio Ferti. & Mineral Ferti. & Organic Fert. & Bio+Organic Fertil. \\
\hline \multicolumn{5}{|c|}{ A- Plant Trap of Okra } \\
\hline 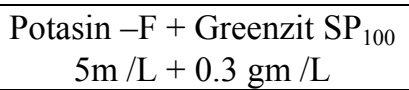 & $0.62 \mathrm{c}$ & $0.66 \mathrm{~b}$ & $0.66 \mathrm{c}$ & $0.92 \mathrm{~b}$ \\
\hline $\begin{array}{r}\text { Radient } \\
0.4 \mathrm{ml} / \mathrm{L} \\
\end{array}$ & $0.77 \mathrm{bc}$ & $0.74 \mathrm{~b}$ & $0.85 \mathrm{bc}$ & $1.03 \mathrm{~b}$ \\
\hline $\begin{array}{c}\text { Dursban } \\
5 \mathrm{~m} / \mathrm{L} \\
\end{array}$ & $0.62 \mathrm{c}$ & $0.70 \mathrm{~b}$ & $0.59 \mathrm{c}$ & $0.96 \mathrm{~b}$ \\
\hline Plant Trap & $0.88 \mathrm{bc}$ & $0.77 \mathrm{~b}$ & $1.11 \mathrm{~b}$ & $1.22 \mathrm{~b}$ \\
\hline \multicolumn{5}{|c|}{ B- Plant Trap of Maize } \\
\hline $\begin{array}{c}\text { Potasin }-\mathrm{F}+\text { Greenzit } \mathrm{SP}_{100} \\
5 \mathrm{~m} / \mathrm{L}+0.3 \mathrm{gm} / \mathrm{L}\end{array}$ & $0.74 \mathrm{bc}$ & $0.85 \mathrm{~b}$ & $0.74 \mathrm{bc}$ & $1.07 \mathrm{~b}$ \\
\hline $\begin{array}{r}\text { Radient } \\
0.4 \mathrm{ml} / \mathrm{L}\end{array}$ & $0.85 \mathrm{bc}$ & $0.70 \mathrm{~b}$ & $0.85 \mathrm{bc}$ & $0.92 \mathrm{~b}$ \\
\hline $\begin{array}{c}\text { Dursban } \\
5 \mathrm{~m} / \mathrm{L} \\
\end{array}$ & $0.70 \mathrm{bc}$ & $0.81 \mathrm{~b}$ & $0.88 \mathrm{bc}$ & $1.11 \mathrm{~b}$ \\
\hline Plant Trap & $1.07 \mathrm{~b}$ & $0.85 \mathrm{~b}$ & $0.81 \mathrm{bc}$ & $1.29 \mathrm{ab}$ \\
\hline \multicolumn{5}{|c|}{ C- Cotton Plants without plant traps } \\
\hline $\begin{array}{c}\text { Potasin }-\mathrm{F}+\text { Greenzit } \mathrm{SP}_{100} \\
5 \mathrm{~m} / \mathrm{L}+0.3 \mathrm{gm} / \mathrm{L}\end{array}$ & $0.88 \mathrm{bc}$ & $1.03 \mathrm{ab}$ & $0.96 \mathrm{bc}$ & $1.14 \mathrm{~b}$ \\
\hline $\begin{array}{r}\text { Radient } \\
0.4 \mathrm{ml} / \mathrm{L} \\
\end{array}$ & $0.81 \mathrm{bc}$ & $0.81 \mathrm{~b}$ & $0.81 \mathrm{bc}$ & $1 \mathrm{~b}$ \\
\hline $\begin{array}{c}\text { Dursban } \\
5 \mathrm{~m} / \mathrm{L}\end{array}$ & $0.85 \mathrm{bc}$ & $0.92 \mathrm{~b}$ & $0.85 \mathrm{bc}$ & $1.03 \mathrm{~b}$ \\
\hline Untreated Check & $1.62 \mathrm{a}$ & $1.40 \mathrm{a}$ & $1.81 \mathrm{a}$ & $1.74 \mathrm{a}$ \\
\hline F Calculated & 3.519 & 2.069 & 5.327 & 1.93 \\
\hline F Tabulated & 1.87 & 1.87 & 1.87 & 1.87 \\
\hline $\operatorname{LSD}_{.05}$ & 0.398 & 0.390 & 0.439 & 0.451 \\
\hline Significant & $* * *$ & $*$ & $* * *$ & $*$ \\
\hline
\end{tabular}

Table 8. Effect of Fertilization types on infestation with Pectinophora gossypiella during season of 2010

\begin{tabular}{lc}
\hline \multicolumn{1}{c}{ Type of Fertilizers } & Mean Numbers of larvae per ten bolls \\
\hline Bio-Fertilization & $0.87 \mathrm{~b}$ \\
\hline Mineral Fertilization & $0.86 \mathrm{~b}$ \\
\hline Organic Fertilization & $0.91 \mathrm{~b}$ \\
\hline Organic + Bio-Fertilization & $1.12 \mathrm{a}$ \\
\hline F Calculated & 6.288 \\
F Tabulated & 2.75 \\
\hline LSD & 0.168 \\
\hline Significant & $*$
\end{tabular}

N.S : Not Significant

Noticeably, the efficiency of each experimented fertilization type, integrating with the other tested agro ecotechniques was assured by the calculated insignificant low means values of pink bollworm infestation of 0.87 larvae / 10 bolls for the bio-fertilized, 0.86 larvae / 10 bolls for the mineral, 0.91 larvae / 10 bolls for the organic versus, the organo-biofertilized plants which gave higher mean number 1.12 larvae / 10 bolls, (Table, 8). 
These above mentioned results; convinced by the statistical analysis of data, confirm the efficient role of followed "push-pull" strategy in the habitat manipulated agro-system of cotton field, in accord integration with the assessed effects of fertilization types; applied foliar sprays of tested nutrients and pesticides on the surrounded cotton plants by the interplanted traps of okra and / or maize plants.

The above cited results are ascertained by the concluded results by EL-Sorady et al. (1998) who determined the percentages of reductions in natural pink bollworm infestation when the insecticides were applied every two weeks at the recommended rate and half of the recommended rate, respectively. Mahar et al. (2004) reported that the all tested (Organo ohosphorous) insecticides: Fenpropthrin, Chlorpyrifos and Endosulfan, were effective against pink bollworm.

Abdel-Rhman (2004) found that the highest reduction in the cotton bollworm infestation were induced by the use of Chlorpyrifos, Tracer $^{\circledR}$ (Spinosad) and Methoxyfenozide ${ }^{\circledR}$.Abd EL-Rahman et al. (2009) indicated that the highest biological performance against the pink bollworm ( $P$. gossypiella) was achieved using g. -cyhalothrin at $100 \mathrm{ml} /$ fed. $(92.7 \%$ ) followed by the mixture of spinetoram at $70 \mathrm{ml}+$ methoxyfenozide at $80 \mathrm{ml}$. Also, the obtained results by Mesbah et al. (2000) were in full agreement with the present aforementioned and illustrated findings.

Dhawan et al. (2006) showed that Spinosad 45\% SC a new formulation as at 50, 75, and 100 g. a.i., gave better control than Chlorpyrifos and Cypermethrin, and equivalent control to that of Tracer and Indoxacarb.

In conclusion, results of the present investigation reveled that, cotton plants provided with crop traps and fertilized with bio-fertilization and sprayed with Potasin-F+ Greenzit $\mathrm{SP}_{100}$, Radiant and/or Durspan significantly recorded the Lower infestation by E, insulana and P. gossypiella

\section{REFERENCES}

Abdel-Rhman, Kh. A (2004). Effect of certain bio and chemical insecticides on the incidence of bollworms, physiological and yield parameters of cotton plants. Adv. Agric. Res., 9(1): 125-136.

Abd El-Rahman, Kh.A; A.Z. EL-Naggar and M. M. ELBasiony (2009). Biological performance of certain green chemistry pesticides and mixtures against the pink bollworm, Pectinophora gossypiella (Lepidoptera: Gelechiidae) (Saund.) and spiny bollworm, Earias insulana (Lepidoptera: Noctuidae) (Boisd.). Nile Delta Conf. on Exports Crops, Fac. of Agric., Minufiya Univ., $1^{\text {st }}: 335-345$.
Dhawan, A.K.; Subash singh; Sarwan Kumar; Ravinder Singh and Ravinder Kumar (2006). Evaluation of Spinosad 45 Sc (Spinosyan A $50 \%$ Minimum and Spinosyan D $50 \%$ Maximum) against bollworms complex in cotton. J. Cotton Res. and Development, 20 (2): 236 - 240.

El-Naggar, A.Z. (1998). Evaluation of certain foliars and micro-elements in an Integrated Pest Management (IPM) program to control cotton bollworms. M.Sc. Thesis, Fac. Agric., (Saba-Bacha), Alex. Univ. Egypt.

EL-Naggar, A.Z (2003). Evaluation of certain new approaches of control measures in an integrated pest management program of cotton bollworms. Ph.D. Fac. Agric., (Saba-Bacha), Alex. Univ., Egypt.

EL-Naggar, A.Z (2009). Efficacy of some foliar fertilizers and alternative chemicals on the spiny bollworm, Eearias insulana (Boisd.) larvae (Lepidoptera: Noctuidae). Alex. j. Agric. Res. 54(1): 139 - 146.

EI-Naggar,A.Z, and Tawfeek, M.E (2012). Efficacy of some foliar fertilizers and alternative chemicals on the spiny bollworm, Earias insulana (Boisd.) larvae (Lepidoptera : Noctuidae) and their side effect on Protease enzyme activity .J. Entomol., 9 (6): 375-381.

EL-Sorady, A.E.M; A.A.S. EL-Zanan; M.K.A. Abo-Shloa and A.A. EL-Dahan (1998). Influence of some insecticides sequences on natural and artificial infestation with pink bollworm, Pectinophora gossypiella (Saund.). Egypt. J. Agric. Res., 76 (2):585 - 596.

Khan, B.S. and J.A. Pickett (2004). Exploiting chemical ecology and species diversity: stem borer and Striga control for maize and sorghum in Africa. Proceedings of the Society of Chemical Industry (SCI) Meeting, VK. Pest Management Science, 56: $1-6$.

Locke, L.F. and H.V. Eck. (1965). Iron deficiency in plants: How to control it in yards and gardens: U.S.D.A. Home and Garden Bull., 102-107.

Mahar, A.N.; M. Munir; D.A. Darban; A.Q. Mahar and G.S. Markhand (2004). Comparative efficacy of different insecticides against spotted bollworms, Earias insulana and E. vittela on different cotton varieties in Sindh, Pakistan. Indus Cottons, 1 (2): 80 - 87.

Mesbah,H.A.; Mahasen M. Ibrahim; H.A.Awad. and A.Z. EINaggar (2004). Performance of Plant Nutrients and Alternative Chemicals against the cotton bollworms: P. gossypiella (Lep.: Gelechiidae) and Earias insullana (Lep. Noctuidae), at El-Beheira Governorate. J.Adv.Agric. Res., 9(3):689-696.

Mesbah, H.A.; Mahasen M. Ibrahim; E.H. Tayeb; A.Z. ElNaggar and Hanyiat M. El-Nimr (2000). Plant health, a new approach for the attainment of tolerant plants to pests infestation. (5): Effect of fertilization and foliar application of nutritive elements on the infestation of cotton with bollworms. Adv. Agric. Res., 5 (2): 14371454. 
Mesbah, H. A.; E.H. Tayeb; M. M. EI-Bassiony and A. Z. EI-Naggar (2005). The efficacy of some plant nutrients and alternative chemicals against the cotton spiny bollworm Earias insulana (Lepidoptera: Noctuidae), at Alexandria Governorate. J.Adv.Agric. Res., 10(4) 10151035.

Michaeal, Treshow (1970). Environment and plant response. Mc Grow-hill book company, pp. 422. poisoning.Bull. Ent. Soc. Egypt, Econ. Ser., 14:492-497.

Njihia, S.; F. Musembi; Z. Khan and F. Muyekho (2005). Control of maize stem borers using the "push-pull" technology in central Kenya. Insect Sci. Appli., 21 (4): $375-380$.
Purohit, M.S. and A.D. Deshpande (1994). Effects of fertilizers on cotton bollworms in relation to plant protection. J. Maharashtra-Agricultural Universities, 19: 172-174.

Pyke, B.; M. Rice; B. Sabine and M. Zalucki (1987). The push-pull strategy - behavioral control of Heliothis. Australian cotton grower May-July: 7 - 9.

Thimmaiah, G. and G.T.T. Raju (1991). Possibilities of using okra (bhendi) as a trap crop in cotton bollworm management. Univ., Agric., Sci., 20(7): 140 - 142.

Wu, G.; Z. Chen; S. Dong; H. Li; J. Au and J. Shi (1991). Influence of interplanting corn in cotton fields on natural enemy populations and its effect on pest control in Southern Shaanxi. Chinese J. Biological control, 7 (3): $101-104$.

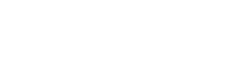

\section{تأثير بهض القنيلت البيئية والزراعية على إصلبة محصطل الفلان بجيدل اللوز الشوكية والفرفلية}

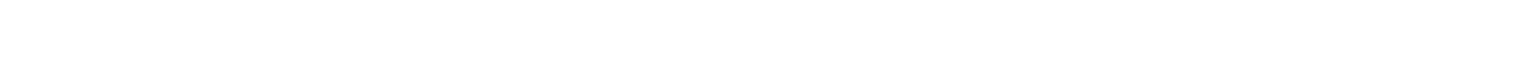

أوضحت النتائج أن النباتلت المسمة الحيويةسجلت أثل

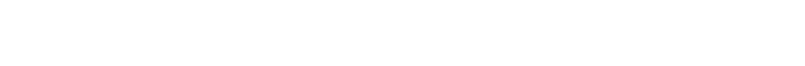

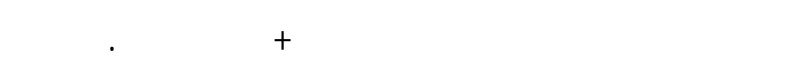

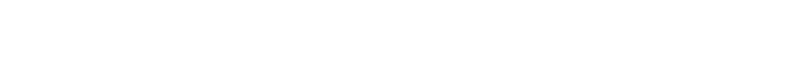

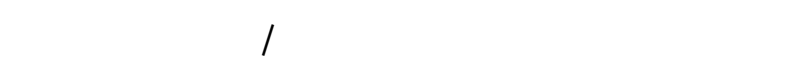

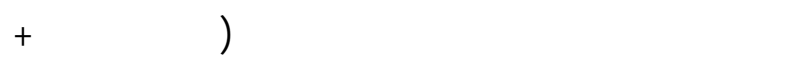

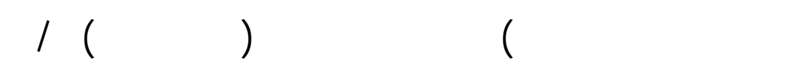

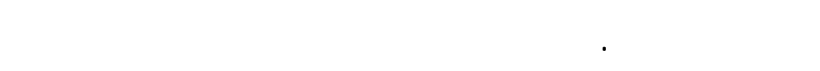

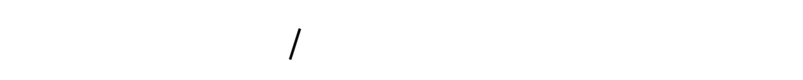
بشها بنلك المعلملات وذك فى كلا علم الدرلسة.
إجريت الدرلسة على صف قطن جيزة 88 وذك خلل

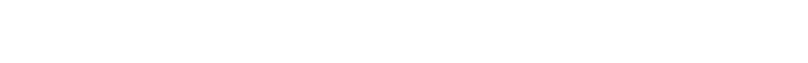

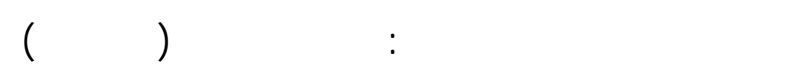

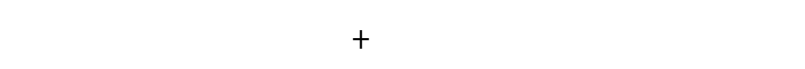

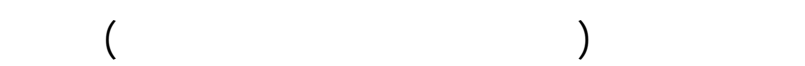

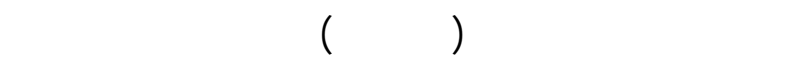

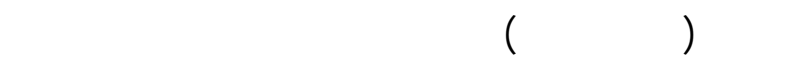

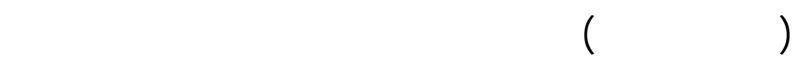
لدوة اللوز اللشوكية والقرفلية. 